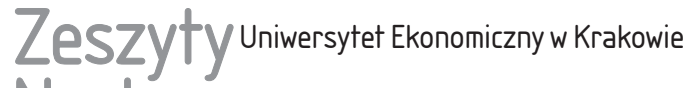 Naukowe
}

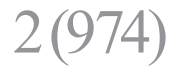

ISSN 1898-6447

Zesz. Nauk. UEK, 2018; 2(974): 133-147 https://doi.org/10.15678/ZNUEK.2018.0974.0208

\author{
Dorota Kędzior \\ Marcin Kędzior
}

\section{Zależność kosztu kapitału jednostek gospodarczych od czynników o charakterze instytucjonalnym}

\section{Streszczenie}

Celem artykułu była krytyczna analiza wybranych czynników instytucjonalnych oddziałujących na koszt kapitału przedsiębiorstw. W artykule przedstawiono uwarunkowania teoretyczne dotyczące kosztu kapitału, najważniejsze metody ustalania kosztu kapitału oraz zależności między ryzykiem a kosztem kapitału. Omówiono wybrane czynniki instytucjonalne oddziałujące na koszt kapitału przedsiębiorstw. Za najważniejsze czynniki instytucjonalne uznano systemy prawne, rozwój giełd papierów wartościowych i sektora bankowego oraz jakość standardów rachunkowości. Podstawową metodą badawczą zastosowaną w opracowaniu była analiza literatury przedmiotu.

Słowa kluczowe: koszt kapitału, giełdy papierów wartościowych, sektor bankowy, systemy prawne, standardy rachunkowości.

Klasyfikacja JEL: G2, G3, F3.

Dorota Kędzior, Uniwersytet Ekonomiczny w Krakowie, Wydział Finansów i Prawa, Katedra Finansów Przedsiębiorstw, ul. Rakowicka 27,31-510 Kraków, e-mail: kedziord@uek.krakow.pl

Marcin Kędzior, Uniwersytet Ekonomiczny w Krakowie, Wydział Finansów i Prawa, Katedra Rachunkowości Finansowej, ul. Rakowicka 27, 31-510 Kraków, e-mail: kedziorm@uek.krakow.pl 


\section{Wprowadzenie}

Koszt kapitału jednostek gospodarczych to jeden z najważniejszych elementów zarządzania finansami przedsiębiorstw. Oddziałuje on istotnie na wartość podmiotu gospodarczego. Przedsiębiorstwa o wysokim koszcie kapitału charakteryzują się wyższym ryzykiem, niższą elastycznością finansową oraz mniejszymi możliwościami pozyskania kapitału zarówno własnego, jak i obcego. Zakres realizowanych inwestycji również będzie mniejszy. Jednostki o wysokim koszcie kapitału mogą realizować jedynie inwestycje o relatywie wysokich stopach zwrotu. Obecnie wysokość kosztu kapitału jest również do pewnego stopnia miarą oceny czy wręcz wizerunku danej firmy wśród inwestorów czy kredytodawców. Często przedsiębiorstwa o niskim koszcie kapitału cechuje: wyższa rentowność, wyższa płynność, dobre praktyki w zakresie nadzoru korporacyjnego, wysokiej jakości sprawozdawczość finansowa oraz realizowanie postulatu społecznej odpowiedzialności biznesu.

W literaturze przedmiotu dominują czynniki finansowe oddziałujące na koszt kapitału, zależne w dużym stopniu od jednostki gospodarczej; są one stosunkowo dobrze opisane i zweryfikowane. Należy się jednak zastanowić, czy pewne ogólne warunki instytucjonalne, prawne i ekonomiczne charakterystyczne dla danej gospodarki oddziałują na koszt kapitału przedsiębiorstw pochodzących z określonego państwa. Przedsiębiorstwa funkcjonujące w różnych państwach niejednokrotnie charakteryzują się różnym poziomem kosztu kapitału. Stąd celem artykułu jest krytyczna ocena wybranych czynników instytucjonalnych oddziałujących na koszt kapitału przedsiębiorstw. Przedmiotem szczegółowej analizy są m.in. obowiązujące systemy prawne, rozwój giełd papierów wartościowych, sektora bankowego oraz jakość standardów rachunkowości.

\section{Teoretyczne uwarunkowania kosztu kapitału}

W literaturze przedmiotu wymienia się wiele definicji kosztu kapitału. A. Duliniec (2011, s. 57) określił koszt kapitału jako oczekiwaną przez inwestorów stopę zwrotu z kapitału przy danym poziomie ryzyka. Podobnie koszt kapitału zdefiniowali M. Sierpińska i T. Jachna (1993, s. 246) - jako cenę, którą płaci kapitałobiorca za możliwość korzystania z kapitału, stanowiącą stopę zwrotu dla inwestora. Koszt kapitału „stanowi minimalną normę efektywności wykorzystania zasobów rzeczowych stworzonych dzięki realizacji projektów inwestycyjnych" (Czekaj i Dresler 2005, s. 79). Koszt kapitału może stanowić stopa procentowa, która określa wynagrodzenie dla kapitałodawcy za udostępnienie kapitału, czyli jest stopą dochodu z inwestycji. 
Głównym celem jednostki gospodarczej jest maksymalizowanie wartości przedsiębiorstwa (Maślanka 2009, s. 30-36; 2007, s. 520-530). Czynnikiem umożliwiającym osiągniecie tego celu jest w dużym stopniu koszt kapitału. Jest on zależny od sposobu finansowania przedsiębiorstwa czy inwestycji - poprzez kapitał własny i kapitał obcy. Jako główne źródło finansowania działalności podmiotu gospodarczego wymienia się kapitał własny pochodzący ze źródeł zewnętrznych oraz wewnętrznych. Efektywność kapitałów własnych może zostać zwiększona poprzez korzystanie z kapitału obcego, o ile jego koszt jest niższy od rentowności majątku. Negatywnym skutkiem zwiększonego wykorzystania kapitałów obcych jest wzrost ryzyka finansowego, które może przyczynić się do nadmiernego wzrostu kosztów finansowych oraz do utraty płynności finansowej (Bień 2005, s. 202). Z drugiej strony uważa się, że koszt pozyskania kapitału obcego jest znacznie tańszy od kapitału własnego. Również efekt tarczy podatkowej wpływa na zmniejszenie kosztu kapitału obcego, gdyż zapłacone odsetki obniżają podstawę opodatkowania.

Przedsiębiorstwa finansują swoją działalność za pomocą różnorodnych źródeł. Przy ustalaniu kosztu kapitału niezbędne jest obliczenie udziału poszczególnych rodzajów zaangażowanego kapitału, a następnie określenie kosztu kapitału jednostki gospodarczej na podstawie średniego ważonego kosztu kapitału (WACC - weighted average cost of capital) (Czekaj i Dresler 2008, s. 82). Kapitał własny może pochodzić ze źródeł zewnętrznych lub wewnętrznych, dlatego należy oddzielnie obliczać koszt kapitału własnego uprzywilejowanego (akcje uprzywilejowane), koszt kapitału własnego z emisji akcji zwykłych oraz koszt kapitału własnego z zysków zatrzymanych (Michalak 2007, s. 75).

Średni ważony kost kapitału wyraża się wzorem:

$$
W A C C=W_{U} \cdot K_{U}+W_{E} \cdot K_{E}+W_{D} \cdot K_{D} \cdot(1-T),
$$

gdzie:

$W_{U}, W_{E}, W_{D}$ - udział odpowiednio kapitału własnego uprzywilejowanego, zwykłego i kapitału obcego w zaangażowanym kapitale,

$K_{U}, K_{E}, K_{D}$ - odpowiednio koszt kapitału własnego uprzywilejowanego i zwykłego, koszt kapitału obcego,

$T$ - stawka podatku dochodowego.

Koszt kapitału własnego może być ustalany za pomocą różnych metod, m.in. modelu wyceny dywidendy (DGM) czy metody stopy zwrotu wolnej od ryzyka powiększonej o premię za ryzyko. Najpowszechniejszą metodą jest model CAPM (capital asset pricing model) - model wyceny aktywów kapitałowych. Został on opracowany równolegle przez trzech ekonomistów: W.F. Sharpa, J. Lintnera i J. Mossina (Czekaj i Dresler 2005, s. 44). Zgodnie z tym modelem koszt kapitału jest równy stopie wolnej od ryzyka powiększonej o premię za ryzyko. W modelu CAPM przyjęto następujące założenia (Hendriksen i van Breda 2002, s. 201): 
- inwestorów charakteryzuje niechęć do ryzyka,

- inwestorzy posiadają jednakowe horyzonty inwestowania oraz takie same preferencje w zakresie średnich, wariancji i kowariancji papierów wartościowych w przyszłości,

- rynek kapitałowy jest rynkiem doskonałym, na kórym nie występują koszty transakcyjne i podatki, a obrót instrumentami finansowymi odbywa się bez ograniczeń.

Ze względu na to, że przyjęte założenia nie są realne, niektórzy autorzy uważają model CAPM za nie w pełni wiarygodny. Model ten odnosi się do przyszłości (ex ante), jednak bazuje na danych z przeszłości. Nie można stwierdzić, że oczekiwane stopy dochodu w przeszłości są równe oczekiwanym stopom dochodu, których model dotyczy (Brigham i Gapenski 2000, s.131). Uważa się, że zmienność współczynnika beta z przeszłości może zostać wykorzystana do określenia zmienności w przyszłości. Założenie to może być wykorzystane tylko wtedy, gdy jego poziom w przeszłości był stabilny - wówczas może on być substytutem oczekiwanego beta.

Wzór na koszt kapitału w modelu CAPM jest następujący (Dziawgo i Zawadzki 2001, s. 166-167):

$$
K A=R o+(R m-R o) \cdot \beta,
$$

gdzie:

$R o$ - stopa zwrotu wolnych od ryzyka dłużnych papierów wartościowych,

$R m$ - średnia stopa zwrotu na rynku kapitałowym,

$\beta$ - wskaźnik relacji zwrotu danej spółki do średniego zwrotu na rynku.

Koszt kapitału obcego wyraża bieżący koszt pozyskania przez jednostkę gospodarczą kapitałów obcych celem sfinansowania jej działalności. Koszt ten jest określony bieżącymi stopami procentowymi oraz ryzykiem niewypłacalności firmy (Analiza sprawozdawczości... 2009, s. 273). Oznacza on w praktyce oprocentowanie kredytów, pożyczek i obligacji własnych. W przypadku kapitału obcego pojawia się efekt tarczy podatkowej, który polega na tym, że zapłacone odsetki stanowią koszt uzyskania przychodu. Wzór na obliczenie kapitału obcego jest następujący (Analiza sprawozdawczości... 2009, s. 273):

$$
K d=k d \cdot(1-t) \cdot 100 \%,
$$

gdzie:

$k d$ - koszt długu,

$t$ - stopa podatku dochodowego.

Podstawy teoretyczne dla ustalenia kosztu kapitału wyznacza jedna z najważniejszych teorii finansów przedsiębiorstw - teoria agencji, której szczególny rozwój przypada na drugą połowę XX w. (Klimczak 2008, s. 64-68). Koszty agencji występują w sytuacji, gdy współpracujące ze sobą strony mają inne cele 
oraz podział zadań, co w szczególności widoczne jest w relacjach przełożony (właściciel)-menedżer (agent). Celem firmy jest maksymalizacja majątku właścicieli, co w praktyce oznacza maksymalizację ceny rynkowej akcji. Nie zawsze cele właścicieli są zbieżne z celami i dążeniami osób pełniących funkcję zarządu, którzy nie są jednocześnie akcjonariuszami spółki (Brigham i Gapenski 2000, s. 44). Zadaniem zarządu jest kierowanie firmą tak, aby maksymalizować jej wartość dla akcjonariuszy oraz dostarczać danych finansowych potwierdzających osiągnięte wyniki finansowe. Rola akcjonariusza sprowadza się natomiast do oceny uzyskanych danych (Grabiński, Kędzior i Krasodomska 2014, s. 42). Potencjalny konflikt na linii właściciel-zarząd pojawia się, kiedy dla menedżera nadrzędnym celem przestaje być maksymalizacja zysku akcjonariuszy, a stają się cele osobiste. Ograniczenie kosztów agencji wymaga od akcjonariuszy poniesienia dodatkowych wydatków motywujących menedżerów do osiągania celów zbieżnych z celami właścicieli, czyli do ponoszenia tzw. kosztów agencji. Głównymi kosztami agencji wymienianymi przez E.F. Brighama oraz L.C. Gapenskiego są koszty kontroli pracy zarządu, powołanie takiej struktury organizacyjnej firmy, która ograniczy niepożądane praktyki zarządu - w szczególności chodzi o powołanie rady nadzorczej reprezentującej akcjonariuszy. Do kosztów agencji zalicza się również koszty alternatywne powstające przy ograniczaniu kompetencji zarządu na rzecz zwiększania roli właścicieli (Brigham i Gapenski 2000, s. 45). W celu ograniczenia kosztów agencji dąży się do zawierania z menedżerami odpowiednich kontraktów, które mogą ograniczyć część ich oportunistycznych zachowań. W głównej mierze dąży się do uzależnienia wynagrodzenia zarządu od wyników finansowych firmy, angażuje się akcjonariuszy do czynnego udziału w podejmowaniu ważniejszych decyzji (Brigham i Gapenski 2000, s. 45). Im wyższe są koszty agencji, tym wyższe jest ryzyko przedsiębiorstwa, a w rezultacie również wyższy jest koszt kapitału.

Konflikty opisane w ramach teorii agencji pomiędzy zarządem a właścicielem wiążą się z podziałem ryzyka, który determinuje koszt kapitału przedsiębiorstwa. Akcjonariusze wykazują znaczną skłonność do podejmowania ryzyka, natomiast zarząd, który jest odpowiedzialny za wyniki przed właścicielami-akcjonariuszami, dąży do jego ograniczenia, tak aby minimalizować zagrożenie bankructwem. Jeżeli w spółce minimalizowane są koszty agencji, co korzystnie wpływa na jej transparentność, to ryzyko danej firmy będzie niższe, a w rezultacie koszt kapitału też będzie mniejszy. Inwestorzy będą wykazywali większą skłonność do inwestowania w przedsiębiorstwa o niższych kosztach agencji.

Na koszt kapitału obok teorii agencji istotnie oddziałuje również teoria asymetrii informacji. Zjawisko to oznacza nieidentyczny dostęp do informacji pochodzących z jednostki gospodarczej dla różnych uczestników gry rynkowej. Asymetria informacji może występować na poziomie zarządu oraz akcjonariuszy. Pozycja 
zarządu będzie w tym przypadku bardziej uprzywilejowana, gdyż menedżerowie mają pełniejszą wiedzę o tym, co dzieje się w jednostce gospodarczej, w stosunku do inwestorów zewnętrznych. Akcjonariusze uzyskują podstawowe informacje o przedsiębiorstwie z publikowanych sprawozdań finansowych oraz sprawozdań z działalności gospodarczej. Dane te ujawniane są z pewnym opóźnieniem, co daje znaczną przewagę menedżerom w zakresie szybkości dostępu do informacji. Zjawisko asymetrii występuje także pomiędzy kredytodawcą a kredytobiorcą. Kredytobiorcy niejednokrotnie nie chcą ujawniać niekorzystnej sytuacji majątkowo-kapitałowej, stąd ustalenie rzeczywistej kondycji finansowej przedsiębiorstwa może być dla banku utrudnione. Pożyczkodawcy natomiast nie są skłonni finansować dochodowych, ale ryzykownych przedsięwzięć inwestycyjnych, ponieważ dodatkowa premia za ryzyko przypadnie kredytobiorcy. Również poszczególne grupy inwestorów mogą mieć różny dostęp do informacji. Uważa się, że inwestorzy instytucjonalni mają większe możliwości pozyskania informacji na temat sytuacji finansowej spółki niż inwestorzy nieinstytucjonalni (Błach 2009). Im wyższe jest zróżnicowanie jakości oraz terminowości w zakresie przekazywanych informacji o przedsiębiorstwie, tym inwestorzy zewnętrzni mogą domagać się wyższych stóp zwrotu z kapitału. Koszt kapitału będzie wyższy w przypadku występowania zjawiska asymetrii informacji. Przedsiębiorstwa powinny więc dążyć do minimalizowania asymetrii informacji oraz ograniczania ryzyka związanego z tym zjawiskiem.

\section{Zależności między ryzykiem a kosztem kapitału}

Koszt kapitału jest w dużym stopniu zależny od poziomu ryzyka. Zgodnie z klasyczną teorią ekonomii wzrost różnorodnie definiowanego ryzyka powoduje wzrost niepewności, a zatem także żądanie wyższej stopy zwrotu przez różne podmioty dostarczające kapitał dla przedsiębiorstwa, stąd koszt kapitału ulega zwiększeniu. W literaturze przedmiotu istnieje bardzo wiele klasyfikacji ryzyka, jednak dla działalności przedsiębiorstwa najistotniejszy jest podział ryzyka na ryzyko systematyczne oraz ryzyko niesystematyczne (Rachunkowość w zarzqdzaniu ryzykiem... 2010, s. 13).

Źródłem ryzyka systematycznego jest otoczenie jednostki gospodarczej, które związane jest z warunkami ekonomicznymi kraju, regulacjami prawnymi, czynnikami politycznymi i społecznymi. Ryzyko to nie podlega kontroli, ale istnieją możliwości jego ograniczenia. Ryzyko systematyczne dotyczy całej firmy i wszystkich podejmowanych działań (Rachunkowość w zarzq̨dzaniu ryzykiem... 2010, s. 13). Wysoka jakość sprawozdawczości finansowej, wyrażonej poprzez wierne odzwierciedlenie rzeczywistej sytuacji finansowej firmy, powoduje zmniej- 
szenie kosztu kapitału (Feltham i Xie 1994, s. 429-453). Wpływa ona na obniżenie ryzyka systematycznego, określanego również mianem ryzyka rynkowego.

Ryzyko niesystematyczne, nazywane też ryzykiem specyficznym, może być przez firmę częściowo kontrolowane i przewidywane. Ryzyko to jest związane z działalnością danego przedsiębiorstwa. Istnieje możliwość jego częściowej dywersyfikacji. Ryzyko specyficzne może być utożsamiane z ryzykiem danej jednostki gospodarczej lub powiązane z ryzykiem danego projektu inwestycyjnego, którego koszt kapitału określany jest jako oczekiwana stopa zwrotu z danego projektu (przedsiębiorstwa), jaką inwestor jest w stanie zaakceptować. Ryzyko związane z daną inwestycją powinno zostać porównane $\mathrm{z}$ kosztem jej finansowania (kapitału) (Duliniec 2007).

K. Jajuga i T. Jajuga (2006, s. 180) dzielą ryzyko na rynkowe i kredytowe. Ryzyko rynkowe mierzy ryzyko danego rodzaju aktywów w kategoriach jego udziału w ryzyku portfela (Brigham i Gapenski 2000, s. 65). Ryzyko rynkowe dotyczy przede wszystkim inwestycji finansowych, w których stopa zwrotu jest funkcją zmian cen, głównie cen instrumentów finansowych (Jajuga i Jajuga 2006, s. 180). Do głównych rodzajów ryzyka rynkowego zalicza się:

- ryzyko stopy procentowej - z ryzykiem tym mamy do czynienia w sytuacji, gdy płatności danego podmiotu uzależnione są od przyszłych stóp procentowych (dotyczy to w głównej mierze długoterminowych kredytów bankowych, sprzedaży na kredyt kupiecki) oraz gdy wycena aktywów lub pasywów uzależniona jest od kształtowania się stóp procentowych w przyszłości. Wycena długoterminowa coraz większej liczby pozycji bilansu według MSSF dokonywana jest przede wszystkim na podstawie zdyskontowanych przepływów pieniężnych, które bazują na stopie procentowej;

- ryzyko kursu walutowego - jest ono związane ze zmianą kursów walutowych i ich wpływem na przedsiębiorstwo. Występuje w sytuacji, gdy wartość zobowiązań i należności wyrażonych w walutach obcych zmienia się niekorzystnie w stosunku do waluty krajowej. Jeżeli sumy pozycji aktywów i pasywów w walucie obcej są sobie równe, to mówimy o tzw. pozycji walutowej zamkniętej. W przypadku braku takiej zależności jednostka gospodarcza jest w większym stopniu narażona na wahania kursów walut (Miciuła 2012, s. 69);

- ryzyko cen akcji - jest ono związane z ryzykiem wahań cen akcji na rynkach finansowych i dotyczy nie tylko samych akcji, ale także instrumentów finansowych, dla których instrumentem bazowym jest cena akcji (Borowski 2014, s. 15).

Ryzyko kredytowe jest związane ze stratami spowodowanymi niewypłacalnością klienta. Występuje ono przede wszystkim w sektorze bankowym, gdzie obowiązuje zasada, że wysoki poziom ryzyka wymaga wyższej bazy kapitałowej oraz wyższej marży bankowej, które stanowią zabezpieczenie przed ewentualnymi stratami wynikającymi ze zmaterializowanego ryzyka. Zasadę tę można odnieść 
również do przedsiębiorstw. Duża jednostka gospodarcza prowadząca działalność na skalę międzynarodową będzie postrzegana jako bardziej wiarygodny partner, dlatego ryzyko kredytowe będzie niższe niż dla firmy lokalnej. Koszt kapitału dużej jednostki tym samym będzie niższy. Wzrost ryzyka rynkowego oraz ryzyka bankowego należy utożsamiać z wyższym kosztem kapitału.

Inną klasyfikacją ryzyka z perspektywy zarządzania finansami przedsiębiorstwa jest jego podział na ryzyko operacyjne i ryzyko finansowe (Rachunkowość w zarzqdzaniu ryzykiem... 2010, s. 15).

Ryzyko operacyjne jest związane ze zmianami w strukturze aktywów zarówno trwałych, jak i obrotowych oraz z ich wpływem na wynik operacyjny (Rachunkowość w zarzqdzaniu ryzykiem... 2010, s. 15). Im wyższy jest poziom kosztów stałych, tym ryzyko operacyjne jest wyższe. Do oceny tego ryzyka wykorzystuje się dźwignię operacyjną.

Ryzyko finansowe jest związane ze zmianami relacji pomiędzy kapitałami własnymi a kapitałami obcymi. Z perspektywy rentowności wzrost udziału kapitału obcego jest zjawiskiem pożądanym, jednak zbyt duży udział zobowiązań może przyczyniać się do trudności finansowych jednostki gospodarczej i wzrostu ryzyka przedsiębiorstwa. Ryzyko finansowe mierzy się za pomocą dźwigni finansowej (Kędzior 2011, s. 135). Całkowite ryzyko przedsiębiorstwa mierzy się za pomocą dźwigni łącznej (dźwignia operacyjna i dźwignia finansowa). Im wyższy jest poziom ryzyka operacyjnego, a w szczególności ryzyka finansowego, tym wyższy jest koszt kapitału.

\section{Oddziaływanie wybranych czynników instytucjonalnych na koszt kapitału przedsiębiorstwa}

W literaturze przedmiotu koszt kapitału jest uwarunkowany bardzo wieloma czynnikami. Można podzielić je na wewnętrzne, instytucjonalne oraz makroekonomiczne. Determinanty instytucjonalne tworzą ogólne warunki funkcjonowania przedsiębiorstw, ułatwiając lub ograniczając prowadzenie polityki operacyjnej, finansowej i inwestycyjnej. Zewnętrzne środowisko funkcjonowania jednostek gospodarczych oddziałuje w pewnym stopniu na ich ryzyko, a w związku z tym również na koszt kapitału. Poniżej omówiono jedynie najważniejsze elementy środowiska instytucjonalnego danego państwa wpływające na koszt kapitału jednostek gospodarczych. Zaliczyć do nich należy poziom rozwoju giełd papierów wartościowych i sektora bankowego, obowiązujące systemy prawne, jakość krajowych oraz międzynarodowych standardów rachunkowości, stabilność walutową państwa, ryzyko polityczne oraz opodatkowanie przedsiębiorstw. 
Obowiązujące systemy prawne ze względu na podstawowe założenia ich tworzenia oddziałują na koszt kapitału przedsiębiorstw. W praktyce gospodarczej należy wyróżnić następujące systemy prawne: angielskie prawo zwyczajowe (English common law), francuskie prawo stanowione (French civil law), niemieckie prawo stanowione (German civil law) czy skandynawskie prawo stanowione (Scandinavian civil law) (Porta i in. 1997). Angielskie prawo zwyczajowe charakteryzuje się wysokim poziomem ochrony inwestorów giełdowych, w szczególności inwestorów mniejszościowych. Głównie na spółki giełdowe nakładany jest obowiązek przekazywania dużej ilości informacji finansowych wysokiej jakości. W ten sposób zmniejsza się asymetria informacyjna. Inwestorzy giełdowi, krajowi i zagraniczni, mając lepszy dostęp do wysokiej jakości informacji, ze względu na niższy poziom ryzyka domagają się niższej stopy zwrotu, zatem koszt kapitału akcyjnego będzie niższy. Angielskie prawo zwyczajowe chroni też w dużym stopniu interesy kredytodawców, co ma odzwierciedlenie w prawie kredytowym, upadłościowym i egzekucyjnym. Niższe ryzyko kredytowe dla banków oznacza niższy koszt kapitału dla przedsiębiorstw. Angielskie prawo zwyczajowe obowiązuje w takich państwach, jak Wielka Brytania, Stany Zjednoczone, Australia, Nowa Zelandia, Kanada i Irlandia. Niemieckie prawo stanowione chroni w dużym zakresie interesy banków, czego wyrazem jest bardzo wysoki poziom rozwoju właśnie tego sektora w państwach takich jak Niemcy, Szwajcaria, Austria, Japonia i Korea Południowa. Wysoki poziom rozwoju tego sektora oznacza niższy koszt kapitału bankowego dla sektora przedsiębiorstw. Rozwój giełd papierów wartościowych w tych państwach jest ograniczony z wielu powodów, również z powodu braku właściwych rozwiązań prawnych w zakresie zabezpieczenia interesów inwestorów giełdowych, dotyczących m.in. dostępu do informacji finansowej. Ważnym źródłem finansowania w tradycji prawa niemieckiego są kredyty bankowe. Relatywnie niższy poziom ochrony zarówno inwestorów giełdowych, jak i sektora bankowego jest charakterystyczny dla tradycji prawa francuskiego. Sytuacja taka skutkuje stosunkowo wyższym poziomem ryzyka dla inwestorów i banków, zatem również wyższym kosztem kapitału. System ten obowiązuje w takich państwach, jak np. Francja, Włochy, Belgia, Hiszpania czy Portugalia. Skandynawski system prawny natomiast chroni prawa inwestorów oraz sektora bankowego w relatywnie wysokim zakresie. Można zatem oczekiwać w państwach takich jak Szwecja, Norwegia, Finlandia czy Dania stosunkowo niskiego kosztu kapitału dla przedsiębiorstw - zarówno własnego, jak i obcego (Kędzior 2011).

Wysoki rozwój giełd papierów wartościowych powoduje, że koszt finansowania poprzez emisję kapitału własnego jest niższy (Beck i in. 2000). Wysoko rozwinięte giełdy papierów wartościowych charakteryzują się dużą liczbą inwestorów indywidualnych, instytucjonalnych i międzynarodowych. Są bardziej 
płynne, w większym stopniu powiązane z pozostałymi dużymi giełdami papierów wartościowych, efektywne informacyjnie, a dostęp do rynków giełdowych jest łatwiejszy również dla małych i średnich przedsiębiorstw. Zjawisko segmentacji rynku oraz asymetrii informacji jest ograniczone. Im wyższy jest poziom rozwoju giełd papierów wartościowych, tym łatwiejsze i mniej kosztowne jest przeprowadzenie emisji kapitału własnego (Bancel i Mittoo 2004). Wysoko rozwinięte giełdy papierów wartościowych występują m.in. w Wielkiej Brytanii, Stanach Zjednoczonych i Holandii.

S.R. Goldberg, J.H. Godwin i J.E. Duchac (2001, s. 13-21) stwierdzili, że istotny wpływ na koszt kapitału ma również poziom płynności rynków finansowych. Płynność rynku jest definiowana jako możliwości emitowania nowych papierów wartościowych bez obniżania ceny papierów wartościowych już dopuszczonych do obrotu. W przypadku przedsiębiorstw zwiększających zapotrzebowanie na kapitał koszt kapitału nie powinien zatem ulegać istotnemu zwiększeniu. Firmy międzynarodowe mogą przyczyniać się do zwiększenia płynności rynku poprzez emisję papierów wartościowych na rynkach zagranicznych oraz do tworzenia spółek zależnych, które będą pozyskiwać kapitał na rynkach lokalnych (Goldberg, Godwin i Duchac 2001, s. 16). Inną determinantą kosztu kapitału wymienianą przez S.R. Goldberga, J.H. Godwina i J.E. Duchaca (2001, s. 16) jest obszar segmentacji rynków kapitałowych. W sytuacji, gdy rynki kapitałowe są w pełni zintegrowane globalnie, papiery wartościowe o porównywalnej stopie zwrotu i zbliżonym poziomie ryzyka powinny mieć taką samą wymaganą stopę zwrotu przy uwzględnieniu ryzyka kursowego i politycznego. Natomiast segmentacja rynku będzie powodować - głównie dla przedsiębiorstw lokalnych bez dostępu do globalnych rynków finansowych - wyższy koszt kapitału. Określenie poziomu segmentacji rynków finansowych jest złożone, stąd bardzo precyzyjny wpływ segmentacji rynków na koszt kapitału będzie trudny do ustalenia w praktyce.

Przedsiębiorstwa prowadzące działalność na skalę globalną mają łatwiejszy dostęp do międzynarodowych rynków finansowych (Grabiński, Kędzior i Krasodomska 2013, s. 272). Uważa się, że duże firmy działające w skali międzynarodowej mają większą wiarygodność i obarczone są mniejszym ryzykiem niż lokalni przedsiębiorcy. Stąd też koszt kapitału takiej jednostki będzie niższy. Na rynkach lokalnych istnieje ograniczona liczba inwestorów, dlatego lokalny podmiot gospodarczy, chcąc pozyskać większy kapitał, możne stanąć przed problemem finansowania swojej dalszej działalności. Koszty transakcyjne związane z pozyskaniem kapitału przez takie firmy są na ogół większe, ograniczony jest ponadto rodzaj papierów wartościowych, które firma może emitować (Stulz 1999).

Rozwój sektora bankowego wywiera istotny wpływ na koszt kapitału obcego. Generalnie im wyższy poziom rozwoju sektora bankowego, tym większa liczba banków oferujących kredyty bankowe, tym większa konkurencja między nimi, 
a w rezultacie możliwe jest obniżenie kosztu kapitału obcego dla przedsiębiorstw (Beck i in. 2000). Na rozwój sektora bankowego wpływa m.in. skłonność gospodarstw domowych do posiadania oszczędności i inwestowania wolnych zasobów pieniężnych w bankach. Jeśli wartość środków pieniężnych zdeponowanych w bankach ulega zwiększeniu, wartość środków pieniężnych możliwych do przekazania w formie kredytów również jest większa. Koszt kapitału obcego może być znacznie mniejszy, jeśli banki są istotnymi akcjonariuszami w sektorze przedsiębiorstw. Z taką sytuacją mamy do czynienia m.in. w Japonii czy Niemczech, gdzie banki są istotnymi inwestorami również w dużych przedsiębiorstwach. Banki są w stanie bezpośrednio nadzorować sytuację finansową tych przedsiębiorstw (jako właściciele i kredytodawcy), mają bezpośredni dostęp do informacji finansowych i niefinansowych istotnych przy ocenie płynności krótko- i długoterminowej, stąd mogą zaakceptować wysoki poziom ryzyka i udzielić dłużnego finansowania po relatywnie niższym koszcie kapitału ${ }^{1}$.

Koszt kapitału należy powiązać również z jakością rachunkowości. Badania przeprowadzone m.in. przez R.W. Yip i D. Young (2012) oraz C. Roberts, P. Weetman i P. Gordona (2008, s. 6-7) wykazały, że wprowadzenie przez przedsiębiorstwa międzynarodowych standardów sprawozdawczości finansowej (MSSF) w większości państw świata przyczyniło się w dużym stopniu do poprawy jakości sporządzanych sprawozdań finansowych, która wyraża się m.in. zwiększoną ich porównywalnością, transparentnością i możliwościami uzyskania wysokiej jakości informacji finansowych (por. Andrzejewski, Maślanka i Mazur-Maślanka 2016). Jakość informacji finansowej oddziałuje korzystnie na koszt kapitału. G. Feltham i J. Xie (1994) stwierdzili, że poprzez zwiększenie porównywalności sprawozdań finansowych nastąpiło obniżenie ryzyka dla inwestorów, co przyczyniło się do obniżenia kosztu kapitału. M.J. Imhof, S.E. Seavey i D.B. Smith (2017) dokonali analizy założeń koncepcyjnych FASB (Financial Accounting Standards Board Rada Standardów Rachunkowości Finansowej), zgodnie z którymi wysoka jakość sprawozdań finansowych sporządzanych według amerykańskich standardów rachunkowości (US GAAP) umożliwia wyższą ich porównywalność. Wyniki badań powyższych autorów pokazują, że związek pomiędzy porównywalnością sprawozdań finansowych a kosztem kapitału jest najsilniejszy w przypadku, gdy asymetria informacji jest wysoka, a rynki kapitałowe są niedoskonałe. $\mathrm{W}$ takiej sytuacji inwestorzy narażeni są na większe ryzyko i w rezultacie oczekują wyższej stopy zwrotu. Badania przeprowadzone przez R.A. Lamberta, Ch. Leuza i R.E. Verrecchię (2012) również pokazują, że asymetria informacji wpływa na większe ryzyko inwestowania, gdyż inwestorzy są obarczeni wyższym ryzykiem

${ }^{1}$ Więcej na ten temat - (Booth i in. 2001). 
dokonania niekorzystnego wyboru, co wiąże się z wyższym kosztem kapitału jako ceną za wyższe ryzyko.

Nie tylko jakość sprawozdań finansowych, ale również poziom konserwatyzmu standardów rachunkowości stosowanych w danym kraju ma wpływ na koszt kapitału przedsiębiorstwa. Stosowne badania w tym zakresie przeprowadził S. Li (2010). Autor ten zauważył, że wyższy poziom konserwatyzmu rachunkowości w danym kraju prowadzi do obniżenia kosztu kapitału własnego oraz obcego. Relacja ta zachodzi głównie w krajach o silnej egzekutywie prawnej, co może wynikać z istotnych powiązań między systemami sprawozdawczości finansowej a skutecznością instytucji i urzędów danego państwa.

Innymi determinantami kosztu kapitału są stabilność waluty krajowej (ryzyko kursu walutowego) oraz ryzyko kraju realizacji inwestycji (Grabiński, Kędzior i Krasodomska 2013, s. 272). Wahania kursów walutowych powodują większą niepewność inwestorów, ponieważ zmianie może ulec poziom zadłużenia czy wielkość wypłacanych dywidend. Inwestorzy będą zatem domagali się wyższych stóp zwrotu z zainwestowanego kapitału. Istotne znaczenie dla kosztu kapitału ma również kraj realizacji inwestycji. Jeżeli otoczenie polityczne i tworzone regulacje prawne będą sprzyjały prowadzeniu działalności operacyjnej, inwestycyjnej i finansowej firmy, to ryzyko inwestowania w papiery wartościowe przedsiębiorstwa będzie niższe i niższy będzie koszt kapitału.

Na osobne wyróżnienie zasługuje opodatkowanie przedsiębiorstw. Im wyższy jest poziom opodatkowania, tym większa jest skłonność przedsiębiorstw do finansowania swojej działalności poprzez dług. W większości państw koszty odsetek od kredytów bankowych zmniejszają podstawę opodatkowania, stąd naturalna tendencja przedsiębiorstw do finansowania swojej działalności poprzez wzrost zadłużenia, ponieważ koszt kapitału obcego ulega dalszemu ograniczeniu (Chaplinsky i Niehaus 1993). Należy jednak pamiętać, że finansowanie poprzez zwiększenie zadłużenia ma swoje ograniczenia. Wzrost zadłużenia oznacza często również zwiększenie ryzyka, zatem koszt finansowania może być wyższy. Substytutem tej formy obniżania podstawy opodatkowania jest nieodsetkowa tarcza podatkowa (DeAngelo i Masulis 1980). Alternatywą może być więc odpowiednio prowadzona polityka rachunkowości czy polityka podatkowa w przedsiębiorstwie lub też wykorzystywanie różnorodnego systemu ulg podatkowych oferowanych przez państwo.

\section{Podsumowanie}

Koszt kapitału ma fundamentalne znaczenie dla sukcesu i rozwoju przedsiębiorstwa. Konflikty na linii zarząd-właściciel, czy właściciele-kredytodawcy 
najczęściej oznaczają wyższe koszty agencji, wzrost ryzyka, a w rezultacie wyższy koszt kapitału. Im wyższa jest asymetria informacyjna, tym większa jest niepewność w zakresie realnej sytuacji finansowej, stąd koszt kapitału ulega zwiększeniu. Im wyższy jest poziom różnorodnie definiowanego ryzyka, tym wyższy jest także koszt kapitału. Należy wyróżnić tutaj zarówno ryzyko wewnątrz, jak i na zewnątrz przedsiębiorstwa. Koszt kapitału zależy zatem od decyzji operacyjnych, inwestycyjnych i finansowych podejmowanych wewnątrz przedsiębiorstwa, ale również od czynników zewnętrznych, takich jak środowisko instytucjonalno-prawne. Istotny wpływ na ryzyko wywierają obowiązujące w danym państwie systemy prawne. Jeśli chronią one interesy inwestorów lub kredytodawców, można spodziewać się, że będą oni domagali się niższej stopy zwrotu za użyczony kapitał. Wysoko rozwinięte, płynne giełdy papierów wartościowych wpływają na niższy koszt emisji kapitału własnego, ułatwiają jego pozyskanie i umożliwiają dynamiczny rozwój przedsiębiorstwa. Znaczny poziom rozwoju sektora bankowego generuje naturalną konkurencję między bankami, w rezultacie której można spodziewać się niższego oprocentowania kredytów bankowych. Wysokiej jakości standardy rachunkowości uwiarygadniają prezentowane dane finansowe, zmniejszają asymetrię informacyjną, zwiększają jakość i zakres ujawnianych informacji, maleje zatem ryzyko rachunkowości i ryzyko dla inwestorów. Można więc spodziewać się, że podmioty gospodarcze stosujące powszechnie akceptowane standardy rachunkowości będą charakteryzować się niższym kosztem kapitału.

\section{Literatura}

Analiza sprawozdawczości finansowej przedsiębiorstwa (2009), red. W. Skoczylas, Stowarzyszenie Księgowych w Polsce, Warszawa.

Andrzejewski M., Maślanka T., Mazur-Maślanka I. (2016), International Financial Reporting Standards (IFRS) and an Issue of Comparability of Assessments of Financial Standing of the Companies Listed on the Warsaw Stock Exchange Made by the Auditors in the Reports on the Audit of the Financial Statements (w:) IFRS: Global Rules \& Local Use, Anglo-American University, Prague.

Bancel F., Mittoo U.R. (2004), Cross-country Determinants of Capital Structure Choice: A Survey of European Firms, ,Financial Management”, vol. 33, nr 4.

Beck T., Demirgüç-Kunt A., Levine R., Maksimovic V. (2000), Financial Structure and Economic Development. Firm, Industry, and Country Evidence, Policy Research Working Paper, nr 2423, The World Bank, Washington, DC.

Bień W. (2005), Zarzq̨zanie finansami przedsiębiorstwa, Difin, Warszawa.

Błach J. (2009), Ewolucja teorii struktury kapitału, „Finanse. Czasopismo Komitetu Nauk o Finansach PAN", nr 1(1).

Booth L., Aivazian V., Demirguc-Kunt A., Maksimovic V. (2001), Capital Structures in Developing Countries, ,The Journal of Finance”, vol. 56, nr 1, https://doi.org/10.1111/ 0022-1082.00320. 
Borowski K. (2014), Miary ryzyka na rynku akcji i obligacji, Difin, Warszawa.

Brigham E.F., Gapenski L.C. (2000), Zarzqdzanie finansami, cz. 1, PWE, Warszawa.

Chaplinsky S., Niehaus G. (1993), The Determinants of Inside Ownership and Leverage, „Quarterly Journal of Business and Economics", vol. 32, nr 4.

Czekaj J., Dresler Z. (2005), Zarzq̨dzanie finansami przedsiębiorstw. Podstawy teorii, Wydawnictwo Naukowe PWN, Warszawa.

DeAngelo H., Masulis R.W. (1980), Optimal Capital Structure under Corporate and Personal Taxation, ,Journal of Financial Economic”, vol. 8, nr 1, https://doi.org/10.1016/ 0304-405x(80)90019-7.

Duliniec A. (2007), Finansowanie przedsiębiorstwa. Strategie i instrumenty, PWE, Warszawa.

Dziawgo D., Zawadzki A. (2001), Finanse przedsiębiorstw. Istota-narzędzia - zarzqdzanie, Stowarzyszenie Księgowych w Polsce, Warszawa.

Feltham G.A., Xie J. (1994), Performance Measure Congruity and Diversity in Multi-task Principal/Agent Relations, ,The Accounting Review”, vol. 69, nr 3.

Goldberg S.R., Godwin J.H., Duchac J.E. (2001), International Treasury Management: Understanding the Cost of Capital, ,Journal of Corporate Accounting \& Finance”, vol. 13, nr 1, https://doi.org/10.1002/jcaf.1203.

Grabiński K., Kędzior M., Krasodomska J. (2013), Globalne uwarunkowania rachunkowości - systemy, procesy, zmiany, PWE, Warszawa.

Grabiński K., Kędzior M., Krasodomska J. (2014), Współczesna rachunkowość na rynkach kapitałowych, Difin, Warszawa.

Hendriksen E.A., van Breda M.F. (2002), Teoria rachunkowości, Wydawnictwo Naukowe PWN, Warszawa.

Imhof M.J., Seavey S.E., Smith D.B. (2017), Comparability and Cost of Equity Capital, „Accounting Horizons”, vol. 31, nr 2, https://doi.org/10.2308/acch-51710.

Jajuga K., Jajuga T. (2006), Inwestycje, Wydawnictwo Naukowe PWN, Warszawa.

Kędzior M. (2011), Międzynarodowa struktura kapitału przedsiębiorstw. Ujęcie rachunkowości i finansów, Wydawnictwo C.H. Beck, Warszawa.

Klimczak K.M. (2008), Ryzyko teorii ekonomii, „Master of Business Administration”, t. $16, \mathrm{nr} 6$.

Lambert R.A., Lenz Ch., Verrecchia R.E. (2012), Information Asymmetry, Information Precision, and the Cost of Capital, ,Review of Finance”, vol. 16, nr 1, https://doi.org/ 10.1093/rof/rfr014.

Li S. (2010), Does Mandatory Adoption of International Financial Reporting Standards in the European Union Reduce the Cost of Equity Capital?, „The Accounting Review”, vol. 85, nr 2, https://doi.org/10.2308/accr.2010.85.2.607.

Maślanka T. (2007), Dylematy memoriałowego pomiaru rentowności (w:) Harmonizacja rynków finansowych i finansów przedsiębiorstw $w$ skali narodowej i europejskiej, red. A. Bogus, M. Wypych, Difin, Warszawa.

Maślanka T. (2009), Wartość czy zysk - rozważania na temat głównego celu zarzq̨dzania finansami przedsiębiorstwa (w:) Bankowość w dobie kryzysu finansowego a perspektywy rozwoju regionów, t. III: Przedsiębiorstwa wobec kryzysu finansowego, red. S. Owsiak, Wyższa Szkoła Bankowości i Finansów w Bielsku-Białej, Bielsko-Biała.

Michalak A. (2007), Finansowanie inwestycji w teorii i praktyce, Wydawnictwo Naukowe PWN, Warszawa. 
Miciuła I. (2012), Wspótczesne metody i instrumenty zarzqdzania ryzykiem walutowym w przedsiębiorstwie, ,Studia i Prace Wydziału Nauk Ekonomicznych i Zarządzania”, nr 28.

Porta R.L., Lopez-de-Silanes F., Shleifer A., Vishny R.W. (1998), Law and Finance, „Journal of Political Economy”, vol. 106, nr 6, https://doi.org/10.1086/250042.

Rachunkowość w zarzqdzaniu ryzykiem w przedsiębiorstwie (2010), red. E. Nowak, PWE, Warszawa.

Roberts C., Weetman P., Gordon P. (2008), International Corporate Reporting - A Comparative Approach, Pearson Education Limited, Harlow.

Sierpińska M., Jachna T. (1993), Ocena przedsiębiorstwa według standardów światowych, Wydawnictwo Naukowe PWN, Warszawa.

Stulz R.M. (1999), Globalization, Corporate Finance, and the Cost of Capital, ,Journal of Applied Corporate Finance”, vol. 12, nr 3, https://doi.org/10.1111/j.1745-6622.1999. tb00027.x.

Yip R.W., Young D. (2012), Does Mandatory IFRS Adoption Improve Information Comparability?, ,The Accounting Review”, vol. 87, nr 5, https://doi.org/10.2308/accr_50192.

\section{Institutional Factors and the Cost of Capital}

(Abstract)

The article presents and critically analyses selected institutional factors affecting the cost of capital for enterprises. The paper presents the theoretical determinants of the cost of capital, the most important methods of determining this cost, and the relationship between it and risk. Selected institutional factors affecting the cost of capital were analysed. Legal systems, the development of stock exchanges, the development of the banking sector and the quality of accounting standards were recognised as the most important institutional factors. Analysis of the subject literature was the basic research method employed.

Keywords: cost of capital, stock exchanges, banking sector, legal systems, accounting standards. 